\title{
Tackling Poverty through Women Empowerment: The Role of Social Capital in Indonesian Women's Cooperative
}

\author{
Endah Widiyanti, Pudjihardjo, Putu Mahardika Adi Saputra \\ Faculty of Economic and Business, Brawijaya University, Indonesia \\ E-mail: endah.lexa@gmail.com
}

Received: September 28, 2017; Accepted: December 11, 2017; Published: February 2, 2018

Permalink/DOI: http://dx.doi.org/10.17977/um002v10i12018p044

\begin{abstract}
Women in poverty discourse are considered as a highly vulnerable group. Women empowerment through micro-financing program is the appropriate way to solve the issue of woman poverty. Women, who often had difficult credit access in a formal financial institution, become facilitated in accessing capital to improve her business by the existence of woman cooperative (Koperasi Wanita). Cooperative is an organization who depicts social capital, which has important elements that refer to network, trust, and norm. The objective of this study was to found out the effect of network, trust, and norm as social capital dimension toward women empowerment and its impact toward poverty. This study used quantitative approach through questionnaire and documentation. The population of this study consists of members of Kelompok Pengusaha dan Pedagang Kecil (KPPK) Kopwan SU "Setia Budi Wanita" in East Java, with samples using 251 respondents. Based on Partial Least Square (PLS) analysis result, it showed that network, trust, and norm social capital dimensions has positive and significant effect toward women empowerment. Network, trust, and norm social capital dimensions have negative and significant effect toward poverty. And women empowerment has negative and significant effect toward poverty.
\end{abstract}

Keywords: social capital, woman empowerment, poverty, cooperative JEL Classification: I32, J16, O15, Z13

\section{INTRODUCTION}

Women in poverty discourse were considered as a highly vulnerable group toward poverty. Even more extreme, when talking about poverty, either in Indonesia or another part of the world, women always exist in it. It was as if poverty was identical with women. Todaro (2001) suggest that majority poor people in the world were women. Women financial source was smaller and unstable relative to men financial source. Dilli et al. (2013) stated that in this world, gender inequality was commonly encountered, particularly in developing countries, whereas many women were facing limitation in their freedom. Generally, developmental scientist consider women as have an important role in development. But the reality showed that women globally poorer than men. They also have lower access to health, education and various freedom forms. Beside the main responsibility of women is to take care the children, and with the owned resources they assume responsibility to break the poverty chain, which is the heritage from generation to generation. Because of that a community should 
empower and invest the resources for women to produce significant developmental impact (Todaro \& Smith, 2013). Lubis \& Saputra (2015) argued that Asian developing countries including Indonesia should maximize their key sectors, in order to utilize their available resources. A study related to the key sectors in either middle-income countries or countries categorized as being in the middle-income trap is worth conducting so that those countries can find the economic development model that is suitable for them use in their period of transition to becoming high-income countries. Based on the elaboration, it is important to involve the role of women in development.

Empowerment has become the important strategy to improve the role and opportunity for women in increasing their economy, through micro-financing program. Microfinancing is an effective way to overcome poverty. Todaro (2001) stated that policy which appropriates to consider to overcome the poverty is poverty alleviation program aimed at improving the abilities and human capital and social capital of the poor. One of the examples is an effort to help the poor to start the micro business on their own. Along with the opinion of Rajivan (2001), stated that macro credit program often is considered as remedy for the poverty problem. The program not only as an instrument so the poor group has access to the formal financial institution, but furthermore become a movement to empower the poor society, especially women, in overcoming their poverty, improving the life quality and developing skills and knowledge of the target group to participate actively in the economic or social field. The micro business development effort done by women is alternative to fulfill the daily needs and improve the family income.

The main problem faced by women to start or continue their business in order to increase their revenue was access toward the capital. Micro businesses that was particularly run in poor household and run by women were difficult to have credit access to the formal financial institution. An organization that was considered to be relevant for micro-businesswoman was Women Cooperative (Koperasi Wanita-Kopwan). Social capital in cooperative has become the important capital to attain its objectives other than material capital. Social capital has important elements which refer to trust, network and norms. Olomola (2002) stated that social capital is very important to start and grow the company, and women entrepreneur, especially in the developing countries. The presence of women cooperative facilitates the women micro-entrepreneur in accessing capital, to improve their autonomy. Women autonomy in improving their life level is the success form of women in managing their business. The improvement of life level of the women will improve the family welfare and impact to the poverty alleviation.

Woman Cooperative Serba Usaha "Setia Budi Wanita" East Java is the biggest women cooperative in Great Malang which up to now still hold the cooperative identity, which today many cooperative deviates from its identity. Anam (2016) wrote that from 765 cooperatives in Malang City recorded, will be frozen 99 cooperatives because of inactivity. The cooperatives after field or administrative verifications just left the name and not conduct its obligation to hold Yearly Member Meeting two years consecutively. Faedlulloh (2015) stated that appropriate organization in depicting the social capital is cooperative. Furthermore, Faedlulloh (2015) stated that cooperative is members based 
organization, and not capital based. So, the development and achievement of cooperative aspiration determined by the member's participation that wants to bear the obligations and perform the member rights responsibly. Social capital has an important role in the cooperative movement. In the research done by Chloupkova et al. (2003) explained that social capital has significant influence in the cooperative movement in Denmark and Poland. In the research presented the data that civil action participation in Denmark twice more than in Poland, and the trust level in Denmark $(73,9 \%)$ more than in Poland $(20,1 \%)$. The cooperative movement in Poland is not developing well, different with Denmark because in Poland the social capital is ever crushed by communist regime whichever ruled there.

Woman Cooperative Serba Usaha "Setia Budi Wanita" East Java pioneered "tanggung renteng" system, which the system widely adopted by other cooperatives. In 2013 Woman Cooperative Serba Usaha "Setia Budi Wanita" East Java, received award as cooperative that has the highest philosophy in East Java Province. In 2011, Woman Cooperative Serba Usaha "Setia Budi Wanita" East Java get achievement in national level as the best entrepreneurship mover cooperative, included in 100 big cooperatives in Indonesia in 2015 and at the rank of 79, that showed its existence that recognized at province and national level. In 2016 the Women Cooperative of Serba Usaha "Setia Budi Wanita" of East Java also as one of ten cooperatives in Indonesia that got certification of ISO 9001: 2008. Based on the elaboration, the study aims at analyzing the influence of dimension of social capital in cooperative and women empowerment towards poverty in Woman Cooperative Serba Usaha "Setia Budi Wanita” East Java.

\section{LITERATURE REVIEW \\ Gender Equality}

Gender is the difference in role, function, and responsibility between men and women which is the result of social construction and could change along with time (Sasongko, 2009). Dilli (2015) suggest that gender equality is the development center for two reasons. First, women's freedom in a community is an integral part of development process. According to Sen (1999), development should be taken as the process where one enjoy freedom, other than the growth of gross national product or individual revenue improvement. This freedom would enable individual to make an independent choice along their life. Second, achievement in democratic and economic development would depend on individual freedom, particularly women (Sen, 1999). Removing conditions which generate inequality between men and women would be relevant not only for an intrinsic reason but also can become "smart economics" in the long term (World Bank, 2011).

\section{Concept of Social Capital}

Bourdieu, as the founder of social capital concept, defines social capital as the aggregate of actual or potential resources which tied together to create a durable network thus institutionalizing mutually profitable acquaintance. Coleman (1988) defined social capital based on its function. According to him, social capital is not a single entity but multiple entities which contain two elements, which are social capital which covers several aspects of social structure and social 
capital which facilitate the certain action of actor either individual or firm within the structure. Social capital refers to the network, norm, and trust which has potential to people's productivity.

Four perspectives of social capital and economic development introduced by Woolcock \& Narayan (2000) are (1) Communitarian view, which gives emphasis to the member participation in various group activities as the measure of social capital. Big social capital will bring positive impact to the community welfare. (2) Network view, which gives emphasis to the association or vertical or horizontal relationship among communities and among groups in communities and companies. The social relationship gives emphasis to the togetherness feeling in group called as bonding social capital, and the relation which passes through the border called as bridging social capital. (3) Institutional view, which considers the network strength of communities at the political, legal, and institutional environments. The institutional view considers the social capital as the independent variable. The institutional policy able to strengthen or weaken the network in communities. (4) Synergy view, as the combination of network view and institutional view. The view considers the alliance and occurred relationship between state bureaucracy and various actors in civil societies. State and communities can cooperate so give benefit each other through the cooperation.

\section{Concept of Empowerment}

The word power in empowerment was meant as "power/daya" thus empowerment was meant to give power (pemberdayaan). Power or daya was meant as having strength from within, but it can be strengthened with strengthening elements absorbed from the outside. Empowerment has two objectives. First of all, it was to release the shackle of poverty and backwardness. Second, it was to strengthen the position of community layer in power structure. Both should be done and became the target of empowerment effort (Kartasasmita, 1996).

Akomolafe (2006) suggest that women empowerment was the development of mental and physical capacity, the strength and skill of women to do something with meaning within their social environment, thus they gain social acknowledgment and able to improve their economic status. The objective of economic empowerment for women was to improve women's social economy status by creating an economy culture which contains knowledge regarding women's role, empowering them with various economy effort and improving women emancipation from poverty.

\section{Concept of Poverty}

World Bank (2000) define poverty as poverty is pronounced deprivation in well being. From this definition, we can assume that poverty was considered as deficiency in welfare. Definition of poverty from Chambers (2013) suggest that poverty is an integrated concept which has five elements, that are (1) proper (the poverty itself), (2) dependency (physical limitation), (3) isolation (isolated or isolation rate), (4) state of emergency (vulnerability) and (5) powerless (unable to do anything), which were called as deprivation trap or "poverty trap". These five elements were commonly linked to one another thus becoming a dangerous poverty trap and lethal to life opportunity for poor individual or family. 


\section{Cooperative}

Cooperative is social capital based organization. Social capital has important meaning for the formation of cooperative and its existence. Cooperative has double characteristics, economic and social. There are two social capital at cooperative as a cooperative principle in conducting organization mechanism, and as the main organizational resources. Four initial principles of cooperative given in International Cooperative Alliance (ICA), that is the membership is voluntary, open, and control done by member in democratic way, member economic participation, and cooperative is run autonomously and democracy can be grouped into the social capital role as the cooperative principle in running the organizational mechanism. While the last three principles, education, training and information, cooperation among cooperatives, and attention to the around communities, relate with the investment in social capital, either intra or extra organization. It is included in the group of social capital role as the main organization resources (Valentinov, 2004).

\section{METHOD}

Type of study used was explanatory study, with quantitative approach. Population in this study was 669 members of Kelompok Pengusaha dan Pedagang Kecil (KPPK) Woman Cooperative Serba Usaha "Setia Budi Wanita" East Java. Based on Slovin calculation, amount of sample was 251 respondents. The sampling technique used was proportionate stratified random sampling. Data collection technique was questionnaire and documentation.

The hypotheses in this study are:

1. Dimension of network, trust, and norm social capital are predicted to have significant effect toward women empowerment in Woman Cooperative Serba Usaha "Setia Budi Wanita” East Java.

2. Dimension of network, trust, and norm social capital are predicted to have significant effect toward poverty in Woman Cooperative Serba Usaha "Setia Budi Wanita" East Java.

3. Women empowerment is predicted to has significant effect toward poverty in Woman Cooperative Serba Usaha "Setia Budi Wanita” East Java.

Data analysis used was descriptive analysis, and inferential analysis used was variance-based SEM which known as Partial Least Square (PLS) with Smart PLS version 2.0. Variable indicators for network social capital (X1), trust social capital (X2), norm social capital (X3), and women empowerment (Y1) were reflexive indicators, measured using Likert scale. To conduct further analysis, transforming of Likert scale in the network social capital, trust social capital, norm social capital, and women empowerment as variable into interval or ratio is conducted using MSI (Method of Successive Interval) transformation technique. MSI transformation is facilitated using excel statistic application. Poverty variable (Y2) was formative indicator, measured using poverty index, by referring to study of Cahyat et al. (2007).

\section{RESULT AND DISCUSSION}

Testing or assessment of structural model was through R-square for dependent construct, Stone-Geisser Q-Square test for predictive relevance, t-test 
and significance of structural path parameter coefficient, that obtained by bootstrapping procedure.

R-square on women empowerment (Y1) is 0.516 , that indicates $51.6 \%$ of women empowerment variance can be explained by network social capital (X1), trust social capital (X2), and norm social capital. The remaining $48.4 \%$ can be explained by other variables outside the study. R square on the poverty (Y2) is 0.635 . It means $63.5 \%$ of poverty variance can be explained by network social capital (X1), trust social capital (X2), norm social capital (X3), and women empowerment (Y1). The remaining $36.5 \%$ can be explained by other variables outside the study.

Q-square test for predictive relevance measures the goodness of fit model and its parameter. Q-square score normally is between 0 and 1 . When Q-square is closer to one, this model is getting better (Ghozali, 2008). Q-square score on this model is 0.823 shows this research model is good because Q-square score is closer to one.

PLS analysis result depicted through the relationship between variables also its coefficient path was showed in Figure 1.

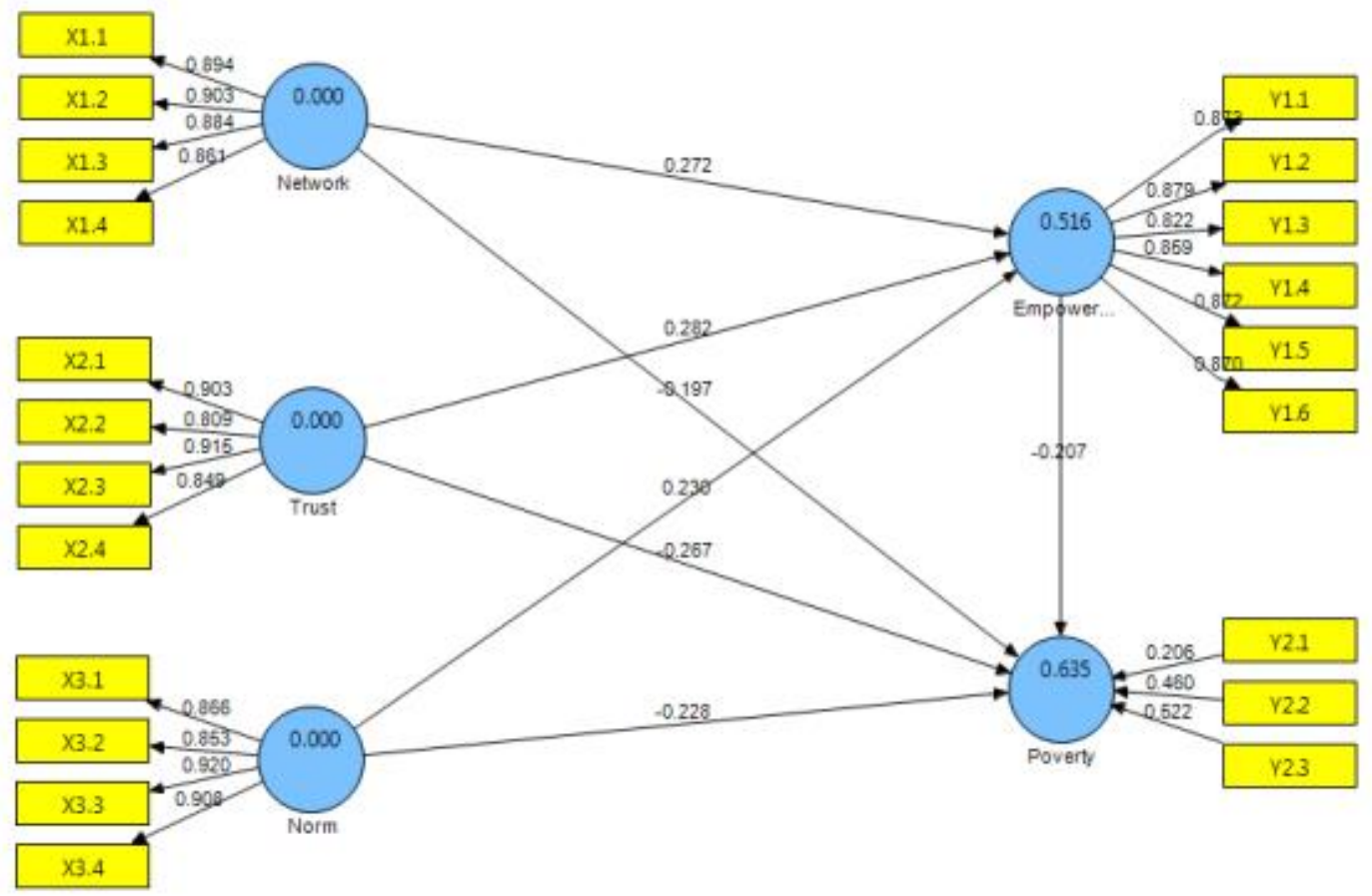

Figure 1. Relationship between Variables and Indicators

Source: Smart PLS's output, 2017

The result of hypothesis testing with t-test through the bootstrap resampling method was showed in Table 1 . If the $t$ value calculated more than $t$ table of 1.96 then can be decided that the relationship between two variables is significant.

Table 1. Hypothesis Testing Result

\begin{tabular}{lccccc}
\hline \multicolumn{2}{c}{ Variables Relationship } & $\begin{array}{c}\text { Path } \\
\text { Coefficient }\end{array}$ & $\begin{array}{c}\mathbf{t} \\
\text { Calculated }\end{array}$ & Description \\
\hline Network & $\rightarrow$ & Empowerment & 0.272 & 3.397 & $\begin{array}{c}\text { Positive and } \\
\text { significant }\end{array}$ \\
\hline
\end{tabular}




\begin{tabular}{lclccc}
\hline \multicolumn{2}{c}{ Variables Relationship } & $\begin{array}{c}\text { Path } \\
\text { Coefficient }\end{array}$ & $\begin{array}{c}\text { t } \\
\text { Calculated }\end{array}$ & Description \\
\hline Trust & $\rightarrow$ & Empowerment & 0.282 & 2.930 & $\begin{array}{c}\text { Positive and } \\
\text { significant }\end{array}$ \\
\hline Norm & $\rightarrow$ & Empowerment & 0.230 & 2.270 & $\begin{array}{c}\text { Positive and } \\
\text { significant }\end{array}$ \\
\hline Network & $->$ & Poverty & -0.197 & 2.563 & $\begin{array}{c}\text { Negative and } \\
\text { significant }\end{array}$ \\
\hline Trust & $->$ & Poverty & -0.267 & 3.116 & $\begin{array}{c}\text { Negative and } \\
\text { significant }\end{array}$ \\
\hline Norm & $->$ & Poverty & -0.228 & 2.434 & $\begin{array}{c}\text { Negative and } \\
\text { significant }\end{array}$ \\
\hline Empowerment & $->$ & Poverty & -0.207 & 3.624 & $\begin{array}{c}\text { Negative and } \\
\text { significant }\end{array}$ \\
\hline
\end{tabular}

Source: Author's computation, 2017

The routine meeting among members in cooperative face to face is important media in communication. Face to face communication creates bonding among members. The strong network relationship is shown with active and repetitive social relationship. Each member will connect with other so they have emotional involvement. The individual capability of the cooperative member to involve themselves in social relationship network is one of success key to building social capital. Coleman (1988) stated that during someone involve in social network and make synergy their strength then directly or indirectly has added the strength to the network. In contrary, by becoming an active part of a network, someone will get additional strength from the network.

Based on the social capital typology, the social relationship between member in a group can be categorized into bonding social capital, because give emphasis to the togetherness feeling in the group. Member in each group tends to be homogenous and selective in accepting a new member. While in general, Woman Cooperative Serba Usaha "Setia Budi Wanita" East Java is an institution with bridging social capital. The member are varied from various background of culture and ethnicity, and each member has the same access to make network in or out of the organization. Bridging social capital will open the way to develop faster with the ability to create strong networking.

Cooperative is members based organization, and not capital based. Therefore cooperative member has an important role in reaching the mutual goals, that is member welfare. As stated by Woolcock \& Narayan (2000), social capital that is considered based on communitarian view which gives emphasis to member participation in various group activities, and the view look that social capital give important contribution in freeing the communities member from poverty.

Based on Figure 1 and Table 1, we can explain that dimension of network social capital has positive and significant effect toward women empowerment, with path coefficient of 0.272 . Through network social capital, the member was easy to gain information, opportunity to participate and to conduct mutual benefit cooperation thus member has the ability to utilize their resources. Tata \& Prasad (2008) suggest that social capital gives an opportunity for a businesswoman to have network in accessing information and resources for business. The result of this study in accordance with the result of Idris and Agbim (2015) which show 
that social capital has significant effect on the economic empowerment of women entrepreneurs in Nigeria.

The dimension of trust social capital has positive and significant effect toward women empowerment, with path coefficient of 0.282 . Trust social capital was useful to obtain aid or loan from cooperative without collateral for their business capital when formal aid from bank was highly limited for women. Loan or credit without collateral toward women as member of cooperative give the ability or strength to its member to initiate or continue their business venture, thus creating women independence. Trust is reflected through the willingness of members to save funds which is the capital of cooperatives in running their business. Putnam (1993) suggests that trust is the key component for social capital. Social capital theory emphasized the importance of trust so that community could function, and to facilitate various social capital results including civilian involvement and democracy.

The dimension of norm social capital has positive and significant effect toward women empowerment, with path coefficient of 0.230 . The implementation of cooperative's values (honesty, openness, responsibility, and caring), members participation of institutional programs' successful, tanggung renteng system implementation, and members compliance to cooperative and group regulation reflect the high norm social capital in Woman Cooperative Serba Usaha "Setia Budi Wanita" East Java. The existence of high norm social capital became the powerful base in each social transaction process and helped to make social matters became more efficient, therefore it would be easier for member to obtain loan in order to improve their power to become more independent. The result of this study was in accordance with the result of Liang et al. (2015) which show that dimension of cognitive or norm social capital has significant effect toward participation of cooperative's members.

The dimension of network social capital has negative and significant effect toward poverty, with path coefficient of -0.197 . Social network owned by the member would raise and extend partnership between members or outsider, thus network social capital in cooperative would open up the business opportunity and marketing opportunity for its members. Network social capital in cooperative would open the access toward information. Information would give insight to improve their life quality, particularly for poor women in obtaining access and opportunity to improve their productivity, thus their income would increase and they would be out of poverty. Putnam (1993) suggest that the difficulties in obtaining information would depend on how many network was owned. More information owned would mean more productive. According to the vicious circle of poverty, productivity would trim poverty.

The dimension of trust social capital has negative and significant effect toward poverty, with path coefficient of -0.267 . Member trust with the ability of executive board to manage cooperative's business and finance would create stable institutional conditions. Member trust with escort officers supports group mentoring more efficiently. Trust among members is demonstrated by applying for unsecured loans and tanggung renteng system that is carried. Trust social capital in Woman Cooperative Serba Usaha "Setia Budi Wanita" East Java showed that there was strong emotional attachment which creates safety feeling so that cooperation would work more effectively, and improving its productivity. 
Productivity improvement would increase revenue and eventually would overcome poverty. Fukuyama (1995) stated that social capital was capability which emerges from general trust within a community or certain part of it. He suggests that a community or nation with high trust would directly proportional with economy welfare improvement.

Dimension of norm social capital has negative and significant effect toward poverty, with path coefficient of -0.228 . High norm social capital would facilitate cooperative's member to obtain loan and thus did not interrupt her productivity. If the member was able to run their business well (high productivity), their income would increase and it has the potential to increase their welfare. Arrow (1999) suggests that if one did not break the norm, the transactional cost wouldn't exist. On the contrary, if one break the norm it would incur loss and thus decrease productivity.

Women empowerment has negative and significant effect toward poverty, with path coefficient of -0.207 . Woman Cooperative Serba Usaha "Setia Budi Wanita" East Java has give access for women to save and to obtain credit. Woman Cooperative has give contribution toward gender equality and women empowerment so that women could increase their productivity and potentially improve their family's welfare. Sen (1999) suggest that women as an agent of change carry an important role in efforts to reduce poverty. This study result was in line with the study of Abdussalam et al. (2013) which suggest that there was the effect of women empowerment to alleviate poverty in Kwara, Nigeria. A study conducted by Saskara et al. (2012) stated that Balinese women who work to earn a living can increase family income, and the family economy will be better.

Based on Table 1 can be known that dimension of trust social capital has a dominant effect toward women empowerment (path coefficient of 0.282 ), and poverty (path coefficient of -0.267) compared to network and norm social capital. It showed that trust social capital is very important to improve the women empowerment and reduce poverty in the Woman Cooperative Serba Usaha "Setia Budi Wanita" East Java compared with other social capital. The open social network and the upholding of norms as control to regulate the members will unable to empower women and eradicate the poverty without high trust. The built trust in women cooperative gives facilitation for women to get loan to begin their business, where poor women experience difficulty in getting access to formal financial institutions because of collateral problem. Because of trust, cooperative get financial capital to run its business through the member savings. This study result was in line with study of La Porta et al. (1997) which show that trust has significant effect toward civic participation and GDP growth. He said that trust promotes cooperation, especially in large organization.

\section{CONCLUSION}

Based on study conducted in Woman Cooperative Serba Usaha "Setia Budi Wanita" East Java, it can be concluded that dimension of network, trust, and norm social capital have positive and significant effect toward women empowerment. High network social capital would facilitate cooperative's member to obtain information and conduct mutual benefit cooperation, thus women would have the ability to utilize their resources. The existence of trust social capital would facilitate women to obtain loan in initiating or continuing/expand their 
business, thus creating women independency. The same goes for high norm social capital whereas activities would be done more efficiently since it did not collide with other valid norms. Dimension of network, trust and norm social capital have negative and significant effect toward poverty. Trust social capital would raise and expand partnership among members or with outsider, thus business opportunity and marketing opportunity would open, and revenue would improve. Women productivity would also improve when trust social capital was high due to strong emotional attachment which creates safety feeling, institutional stability, and more effective cooperation. High norm social capital would facilitate member of cooperative in obtaining loan so that it did not interrupt with her productivity. If member were able to run their productivity well, their income would increase and as well as the potential to improve welfare.Women empowerment has negative and significant effect toward poverty. Member of cooperative has the strength to contribute in economy, has independency in taking decisions, also they have selfconfidence, thus improving their capacity against poverty. Woman Cooperative Serba Usaha "Setia Budi Wanita" East Java has given access for woman to save and obtain credit so that they could improve their productivity and have the potential to improve women's and her family's welfare. The dimension of trust social capital has a dominant effect toward women empowerment, and poverty compared to network and norm social capital. The open social network and the upholding of norms as control to regulate the members will unable to empower women and eradicate the poverty without high trust. The built trust in women cooperative gives facilitation for women to get loan without collateral. Because of trust, cooperative get financial capital to run its business through the member savings.

\section{REFERENCES}

Abdussalam, O. I., Fuadah, J., \& Alias, M. H. (2013). The Determinants of Women Empowerment and Its Impact on Poverty Alleviation: A Case of Kwara State, Nigeria (A Pilot Study). Asian Journal of Social Sciences \& Humanities, 2(4), 342-347.

Akomolafe, C. O. (2006). Open and Distance Learning as a Mechanism for Women Empowerment in Nigeria. Educational Foundations and Management. Retrieved from http://pcf4.dec.uwi.edu

Anam, C. (2016). 99 Koperasi di Kota Malang Segera Dibekukan. Retrieved from industri.bisnis.com.

Arrow, K. J. (1999). Observations on Social Capital. In Partha D., and Ismail, S. (eds), Social Capital: A Multifaceted Perspektive. Washington D.C: The World Bank.

Cahyat, A., Gonner, C., \& Haug M. (2007). Mengkaji Kemiskinan dan Kesejahteraan Rumah Tangga: Sebuah Panduan Contoh dari Kutai Barat, Indonesia. Bogor: Center for International Forestry Research.

Chambers, R. (2013). Rural Development: Putting the Last First. New York: Routledge.

Chloupkova, J., Svendsen, G. L. H., \& Svendsen, G. T. (2003). Building and Destroying Social Capital: The Case of Cooperative Movements in Denmark and Poland. Agriculture and Human Values, 20(3), 241-252. 
Coleman, J. S. (1988). Social Capital in the Creation of Human Capital. American Journal of Sociology: Supplement, Organizations and Institutions: Sociological and Economic Approaches to the Analysis of Social Structure, 94, 95-120.

Dilli, S., Rijpma, A., \& Carmichael, S. (2013). Development versus Legacy: The Relative Role of Development and Historical Legacies in Achieving Gender Equality. CESifo Working Paper, No. 4411.

Dilli, S. (2015). A Historical Perspective on Gender Inequality and Development in the World Economy, c. 1850-2000. Dissertation. Utrecht University Repository.

Faedlulloh, D. (2015). Modal Sosial dalam Gerakan Koperasi. The Indonesian Journal of Public Administration, 1(1), 5-19.

Fukuyama, F. (1995). Trust: The Social Virtues and the Creation of Prosperity. London: Penguin Books.

Ghozali, I. (2008). Structural Equation Modeling: Metode Alternatif dengan Partial Least Square. Edisi Dua. Semarang: Badan Penerbit Universitas Diponegoro.

Idris, A. J., \& Agbim, K. C. (2015). Effect of Social Capital on Poverty Alleviation: A Study of Women Entrepreneurs in Nasarawa State, Nigeria. JORIND, 13(1), 208-222.

Kartasasmita, G. (1996). Pembangunan untuk Rakyat: Memadukan Pertumbuhan dan Pemerataan. Jakarta: CIDESINDO.

Liang, Q., Huang, Z., Lu, H., \& Wang, X. (2015). Social Capital, Member Participation, and Cooperative Perfomance: Evidence from China's Zhejiang. Journal of International Food and Agribusiness Management Review, 18(1), 49-78.

La Porta, R., Lopez-de-Silanes, F., Shleifer, A., \& Vishny, R. W. (1997). Trust in large organizations. American Economic Review, Papers and Proceedings, 87(2), 333-338.

Lubis, R. F., \& Saputra, P. M. A. (2015). The Middle-Income Trap: Is There A Way Out For Asian Countries? Journal of Indonesian Economy and Business, 30(3), 273-287.

Olomola, A.S. (2002). Social Capital, Microfinance Group Performance and Poverty Implications in Nigeria. Ibadan: Nigerian Institute of Social and Economic Research. Retrieved from http://citeseerx.ist.psu.edu.

Putnam, R. (1993). The Prosperous Community: Social Capital and Public Life. Retrieved from https://www.prospect.org.

Rajivan, A. (2001). Micro Credit and Women's Empowerment: A Case Study of SML (SHARE Microfinance Ltd.). United Nations Development Program (UNDP). Draft. Retrieved from https://www.microfinancegateway.org.

Saskara, I. A. N., Pudjihardjo, M., Maskie, G., \& Suman, A. (2012). Tinjauan Perspektif Ekonomi dan Nonekonomi Perempuan Bali yang Bekerja di Sektor Publik: Studi Konflik Peran. Jurnal Aplikasi Manajemen, 10(3), 542-552.

Sasongko, S. S. (2009). Konsep dan Teori Gender. Cetakan Ke Dua. Jakarta: Pusat Pelatihan Gender dan Peningkatan Kualitas Perempuan, BKKBN.

Sen, A. (1999). Development As Freedom. New York: Anchor Books. 
Tata, J., \& Prasad, S. (2008). Social capital, collaborative exchange and microenterprise performance: The role of gender. International Journal of Entrepreneurship and Small Business, 5(3/4), 373-385.

Todaro, M. P. (2001). Pembangunan Ekonomi di Dunia Ketiga. Alih bahasa Haris Munandar. Edisi 7. Jakarta: Erlangga.

Todaro, M. P., \& Smith, S. C. (2013). Pembangunan Ekonomi. Jilid I Edisi 11. Jakarta: Erlangga.

Valentinov, V. (2004). Toward a Social Capital Theory of Cooperative Organisation. Journal of Cooperative Studies, 37(3), 5-20.

Woolcock, M., \& Narayan, D. (2000). Social Capital Implications for Development Theory, Research and Policy. The World Bank Research Observer, 12(2), 225-249.

World Bank. (2000). World Development Report 2000/2001: Attacking Poverty. Retrieved from https:// siteresources.worldbank.org.

World Bank. (2011). World Development Report 2012: Gender Equality and Development. Retrieved from http:// siteresources.worldbank.org. 